\section{Haemodynamic and cat- echolamine responses to calcitonin gene-related peptide during volatile anaesthesia}

\author{
Shohei Takeda MD, \\ Teruaki Tomaru MD, \\ Yutaka Inada MD
}

Purpose: Calcitonin gene-related peptide (CGRP) produces vasodilatation, hypotension, and tachycardia. Tachycardia induced by CGRP may be due to sympathetic activation. Volatile anaesthetics attenuate activation of arterial baroreflexes. We examined the haemodynamic and endocrine effects of CGRP infusion ( $\left.4 \mu \mathrm{g} \cdot \mathrm{kg}^{-1}\right)$ during anaesthesia with either enflurane or isoflurane in dogs.

Methods: Measurements of haemodynamic variables and hormone assays for plasma catecholamines were made before, during, and after CGRP infusion. Anaesthesia consisted of induction with $25 \mathrm{mg} \cdot \mathrm{kg}^{-1}$ pentobarbital, followed by either enflurane $(n=7)$ or isoflurane $(n=7)$ to achieve a 1.0 end-tidal minimum alveolar concentration in oxygen $100 \%$.

Results: Mean arterial pressure and systemic vascular resistance decreased $(P<0.01)$ and the reductions in both variables were similar during CGRP infusion in both groups. Cardiac index $(\mathrm{Cl})$ was increased $(P<0.01)$ in the enflurane group throughout the study while $\mathrm{Cl}$ increased $(P<0.01)$ only during infusion in the isoflurane group. Heart rate $(H R)$ remained unchanged (from 135 $56 \mathrm{bpm}$ to $134 \pm 7 \mathrm{bpm}$ ) in the enflurane group but tended to increase (from 162 \pm 9 $\mathrm{bpm}$ to $171 \pm 9 \mathrm{bpm})$ in the isoflurane group during infusion. Intergroup differences in HR were found $(P<0.05)$. Plasma epinephrine concentrations increased (from $42.4 \pm 12.7 \mathrm{pg} \cdot \mathrm{ml}^{-1}$ to $115.3 \pm 41.8 \mathrm{pg} \cdot \mathrm{ml}^{-1}, P<0.01$ ) during infusion in the isoflurane group. However, these increases were suppressed (from $46.6 \pm 23.2 \mathrm{pg} \cdot \mathrm{ml}^{-1}$ to $64.7 \pm 32.4 \mathrm{pg} \cdot \mathrm{ml}^{-1}$ ) to a greater extent in the enflurane group.

Conclusion: The haemodynamic responses, except for HR, of CGRP infusion are similar during enflurane and isoflurane anaesthesia. Suppression of tachycardia induced by CGRP is greater with enflurane than with isoflurane. The differences in HR may be due to the roles of catecholamine responses resulting from the anaesthetic-induced sympathetic suppression.

Objectif : Le peptide lié au gène de la calcitonine (PLGC) produit une vasodilatation, de l'hypotension et de la tachycardie. La tachycardie induite par le PLGC peut être due à une activation sympathique. Les anesthésiques volatils atténuent l'activation des baroréflexes artériels. Nous avons étudié les effets hémodynamiques et endocriniens d'une perfusion de PLGC ( $\left.4 \mu \mathrm{g}^{\circ \mathrm{g}^{-1}}\right)$ pendant l'anesthésie avec de l'enflurane ou de l'isoflurane chez les chiens.

Méthode : La mesure des variables hémodynamiques et le dosage hormonal des catécholamines plasmatiques ont été faits avant, pendant et après la perfusion de PLGC. L'anesthésie s'est déroulée comme suit : une induction avec $25 \mathrm{mg} \cdot \mathrm{kg}^{\prime}$ de pentobarbital, suivie de l'administration d'enflurane $(n=7)$ ou d'isoflurane $(n=7)$ pour produire une concentration alvéolaire minimale de fin d'expiration de 1,0 dans $100 \%$ d'oxygène.

Résultats : La tension artérielle moyenne et la résistance vasculaire générale ont diminué $(P<0,01)$ et les réductions enregistrées pour les deux variables ont été similaires pendant la perfusion de PLGC dans les deux groupes. Lindex cardiaque $(I C)$ a augmenté $(P<0,0 I)$ dans le groupe enflurane tout au long de l'expérience tandis que l'IC a augmenté $(P<0,01)$ seulement pendant la perfusion dans le groupe isoflurane. La fréquence cardiaque $(F C)$ est demeurée la même (de 135 \pm 6 bpm à $134 \pm 7$ bpm) dans le groupe enflurane, mais a eu tendance à augmenter (de $162 \pm 9 \mathrm{bpm}$ a $171 \pm 9 \mathrm{bpm}$ ) dans le groupe isoflurane pendant la perfusion. On a trouvé des différences de FC intergroupes $(P<0,05)$. Les concentrations plasmatiques d'épinéphrine se sont accrues (de $42,4 \pm 12,7 \mathrm{pg} \cdot \mathrm{ml}^{-1}$ à I 15,3 $\pm 41,8 \mathrm{pg} \cdot \mathrm{ml}^{-1}, P<0,01$ ) pendant la perfusion dans le groupe isoflurane. Cependant, ces augmentations ont été supprimées (de $46,6 \pm 23,2 \mathrm{pg} \cdot \mathrm{ml}^{-1}$ à $64,7 \pm 32,4 \mathrm{pg} \cdot \mathrm{ml}^{-1}$ ) pour la plupart dans le groupe enflurane.

Conclusion : Les réactions hémodynamiques, sauf pour la FC, de la perfusion de PLGC sont similaires pendant l'anesthésie à base d'enflurane ou d'isoflurane. La suppression de la tachycardie induite par le PLGC est plus importante avec l'emploi d'enflurane qu'avec celui de l'isoflurane. Les différences de FC peuvent être attribuées à la réponse aux catécholamines résultant de la suppression sympathique induite par l'anesthésie.

From the Department of Anesthesiology, Showa University Fujigaoka Hospital, 1-30 Fujigaoka, Aoba-ku, Yokohama 227-8501, Japan. Address correspondence to: Shohei Takeda MD. Phone: 81-45-971-1151; Fax: 81-45-973-1019.

Presented in part at the 11th World Congress of Anaesthesiologists, Sydney, April 14-20, 1996 and at the ASA Meeting, New Orleans, October 19-23, 1996. Supported by a Grant-in-aid (No:04807115) for Scientific Research (C) from the Ministry of Education, Science, Sports, and Culture, Japan.

Accepted for Publication September 3, 1998 


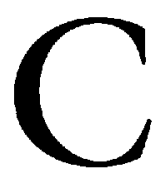

ALCITONIN gene-related peptide (CGRP) is produced from an alternative processing of the RNA transcribed from calcitonin genes, which resulted in the production of a messenger RNA distinct from mRNA that encodes the calcitonin precursor. ${ }^{1}$ The physiological effects of CGRP are multiple on the cardiovascular, gastrointestinal, endocrine, and central nervous systems. ${ }^{2}$

Calcitonin gene-related peptide produces potent haemodynamic actions including vasodilatation, hypotension, and tachycardia. It is the most potent endogenous vasodilator studied in humans to date. ${ }^{3}$ In addition, this tachycardia is associated with an increase in plasma catecholamine concentrations in conscious humans ${ }^{4,5}$ and animals, ${ }^{6-8}$ indicating that it is likely caused by reflex sympathetic stimulation. The increase in heart rate induced by CGRP is abolished by the beta-adrenoceptor blocker, propranolol, ${ }^{9}$ and also is markedly attenuated in sinoaortic denervated rats $^{7}$ and cardiac-denervated dogs, ${ }^{8}$ indicating that this change is mediated primarily by the autonomic nervous system in intact animals. However, the hypotensive and vasodilatory activities of CGRP are not affected by cardiac denervation. ${ }^{7,8}$ Therefore, reflex tachycardia caused by CGRP is suppressed by the control of reflex sympathetic stimulation.

Volatile anaesthetics ${ }^{10-12}$ produce varying suppression of arterial baroreflexes and act indirectly on the autonomic nervous system. We have previously reported that CGRP-induced reflex tachycardia was suppressed by halothane anaesthesia but could be elicited during pentobarbital anaesthesia. ${ }^{13}$ These haemodynamic profiles of CGRP during halothane anaesthesia suggest that CGRP may have a therapeutic application in the perioperative period when used together with volatile anaesthetics. The current study was designed to elucidate the possibility of using CGRP as a vasodilating agent during volatile anaesthesia. For comparison, isoflurane and enflurane were chosen to determine their haemodynamic, catecholamine responses, and carbohydrate metabolism when used with CGRP.

\section{Materials and methods}

All experimental procedures and the protocols for this study were approved by the Animal Experimental Ethics Committee of Showa University Fujigaoka Hospital. Fourteen healthy adult mongrel dogs of either sex weighing between 13 and $21 \mathrm{~kg}(15.7 \pm 0.6 \mathrm{~kg}$, mean $\pm S E M)$ fasted overnight were anaesthetized with $25 \mathrm{mg} \cdot \mathrm{kg}^{-1}$ sodium pentobarbital $i v$. After tracheal intubation, the lungs were mechanically ventilated with a volume cycled animal ventilator (Model 613, Harvard Respirator, South
Natick, MA, USA) to maintain normocapnia until measurements of baseline values were obtained. Anaesthesia was maintained with enflurane $2.1 \%$ or isoflurane $1.3 \%$ at a 1.0 minimum alveolar concentration $(\mathrm{MAC})^{14}$ via an Ohmeda Vaporizer (BOC Health Care, Windlesham, UK) using oxygen as the carrier gas at a flow of 3 to 5 1 - min $^{-1}$ throughout the experiment. End-tidal volatile anaesthetic and $\mathrm{CO}_{2}$ concentrations were measured continuously by an infrared analyzer (Capnomac Ultima, Datex, Helsinki, Finland).

\section{Instrumentation}

Cannulae were placed the left femoral artery for continuous systemic blood pressure (SBP) monitoring and blood sampling, and into the right femoral vein for drug administration. Normal saline was infused at a rate of 7 $\mathrm{ml} \cdot \mathrm{kg}^{-1} \cdot \mathrm{hr}^{-1}$ together with the infusion of CGRP. Arterial blood samples were drawn anaerobically from the femoral cannula. Arterial blood was analyzed for $\mathrm{pHa}, \mathrm{PaCO}_{2}, \mathrm{PaO}_{2}$, and base excess using a blood gas analyser (Radiometer ABL505, Copenhagen, Denmark). A 7-F flow-directed pulmonary catheter (Swan-Ganz thermodilution catheter, Baxter Healthcare, Irvine, CA, USA) was advanced into a pulmonary artery via the right external jugular vein and positioned by pressure monitoring in a branch of the pulmonary artery for the measurement of right atrial pressure (RAP), pulmonary artery pressure (PAP), pulmonary capillary wedge pressure (PCWP), and cardiac output (CO). The $\mathrm{CO}$ was measured in triplicate by the thermodilution technique. We used a cardiac output computer (MTC6210, Nihon Kohden, Tokyo, Japan) and injected $5 \mathrm{ml}$ cold, temperature-monitored normal saline into the right atrium at the end of expiration. Heart rate (HR) was calculated from lead II of the electrocardiogram (ECG) using a cardiotachometer (AT601G, Nihon Kohden), which was continuously monitored.

Each pressure monitoring catheter was connected to a pressure transducer (Uniflow, Baxter Healthcare). The SBP and ECG were monitored continuously on a polygraph (RM6200, Nihon Kohden) and recorded with an eight-channel pen recorder (VM-640G, Nihon Kohden). The animals were fixed in the supine position during the measurements, and the zero reference was leveled at midchest. Mean arterial pressure (MAP) and mean pulmonary artery pressure (MPAP) were determined electronically. Body temperature, monitored by a thermistor attached to the pulmonary artery catheter, was maintained at $37.0 \pm 1.0^{\circ} \mathrm{C}$ with electric heating pads and lamps. Cardiac index (CI), stroke volume index (SVI), and systemic vascular resistance (SVR) were calculated using standard formulas. 
The CI and SVI were calculated as cardiac output and stroke volume divided by the body surface area (BSA), respectively. The $\mathrm{BSA}^{15}$ was calculated as $0.112 \mathrm{X}$ body weight. ${ }^{2 / 3}$ The SVR was calculated as (MAP$\mathrm{RAP}) \cdot \mathrm{CO}^{-1} \times 80$.

\section{Experimental protocol}

The 14 dogs were divided into two groups: The enflurane group $(\mathrm{n}=7)$ anaesthetized with 1.0 MAC enflurane. The isoflurane group $(n=7)$ anaesthetized with 1.0 MAC isoflurane.

After completion of surgical preparation, animals were observed for approximately $60 \mathrm{~min}$ to allow haemodynamic variables (SBP, MPAP, and HR) to stabilize. Measurements of baseline values for the haemodynamics and the hormone assay were obtained before infusion of CGRP. After baseline measurements were made, the enflurane and isoflurane groups received 4 $\mu \mathrm{g} \cdot \mathrm{kg}^{-1}$ CGRP, dissolved in bovine serum albumin $0.1 \%$ in $50 \mathrm{ml}$ of saline $0.9 \%$, which was infused for 60 $\mathrm{min}$ into the left femoral vein at constant rates in both groups with an infusion pump (STG-521, Terumo, Tokyo, Japan). Measurements of haemodynamic variables were taken at 5,30 , and $60 \mathrm{~min}$ after commencement of the infusion of CGRP, and 10,30, and $60 \mathrm{~min}$ after the termination of the CGRP infusion. Measurements of plasma catecholamines, glucose, and lactic acid concentrations were taken 30 and $60 \mathrm{~min}$ after commencement of the infusion of CGRP, and 30 min after termination of the CGRP infusion. We used Des-1-Ala, des- $\alpha$-amino chicken CGRP which has been identified as having a 4 amino acid difference from human $\operatorname{CGRP}(\alpha)$.

\section{Plasma catecholamine assays}

The arterial blood samples were transferred to an icechilled centrifuge tube containing $10 \mathrm{mg}$ sodium ethylenediamine tetraacetic acid (EDTA-2Na). After mixing the blood by gentle inversion, the plasma for the catecholamine assays was separated from the blood cells by centrifugation $(4,000 \times \mathrm{g})$ at $4^{\circ} \mathrm{C}$ for $10 \mathrm{~min}$ and stored at $-80^{\circ} \mathrm{C}$ until assayed.

Free catecholamines were measured by fully automated high-performance liquid chromatography using a diphenylethylenediamine condensation method (HLC-725 Catecholamine Analyzer, Tosoh, Tokyo, Japan). A $600 \mu \mathrm{l}$ aliquot of plasma was mixed with 300 $\mu \mathrm{l}$ perchloric acid $6 \%$ solution by a vortex-mixer for deproteination. After adding $200 \mu \mathrm{l} 1.5 \mathrm{~mol} \cdot \mathrm{l}^{-1}$ sodium acetate, the mixture was stirred and centrifuged (14, $000 \times \mathrm{g}$ ) at $4^{\circ} \mathrm{C}$ for $20 \mathrm{~min}$. The clear supernatant was placed in the autosampler of a high-performance liquid chromatography analyzer. Specifically, the sample was instilled into a precolumn (TSK precolumn $\mathrm{CAl}, 7.5 \times$ $75 \mathrm{~mm}$ ) with the preparation eluent A (sodium perchlorate, sodium citrate, sodium azide) using a microprocessor-controlled column switching device. The eluate was instilled into another precolumn (TSK precolumn CA2, $4 \times 60 \mathrm{~mm}$ ) equilibrated with preparation eluent $B$ (acetonitrile, sodium citrate). Absorbed catecholamine was eluted with analytical eluent $\mathrm{C}$ (ethanol, ammonium nitrate) and instilled into an analytical column (TSK gel, catecholpak $6 \times 150 \mathrm{~mm}$ ). The separated catecholamines were subjected to a reaction coil $\left(90^{\circ} \mathrm{C}\right.$ ) with fluorogenic reagent $\mathrm{D}$ (diphenylethylenediamine in $\mathbf{5 0 \%}$ ethanol solution) as well as reagent $\mathrm{E}$ (ethanol, potassium hexacyanoferrate, boric acid, ascorbic acid) and the catecholamines were converted to diphenylethylenediamine derivatives. The fluorescent intensity of the eluate from the reaction unit was measured in a detector at $470 \mathrm{~nm}$ wavelength with an excitation wavelength at $355 \mathrm{~nm}$. The detection limit of both norepinephrine and epinephrine was $5 \mathrm{pg} \cdot \mathrm{ml}^{-1}$. The intra-assay coefficients of variation for measurements of norepinephrine and epinephrine were 0.69$2.43 \%$ and $0.85-2.73 \%$, respectively. The inter-assay coefficients of variation for measurements of norepinephrine and epinephrine were $2.08-2.91 \%$ and 2.14 $3.54 \%$, respectively.

\section{Measurement of plasma glucose and lactic acid}

Plasma glucose concentration was measured by the glucose dehydrogenase method (Merkeauto glucose, Kantokagaku, Tokyo, Japan). Plasma lactic acid concentration was measured by the lactate oxidase method (Determiner-LA, Kyowa Medics, Tokyo, Japan).

\section{Statistical analysis}

Values are expressed as mean \pm SEM. Intragroup differences (haemodynamic, catecholamine, glucose, lactic acid, and blood gas data) were analyzed by a two-way analysis of variance from repeated measurements of the same variables followed by Dunnett's test when appropriate. Intergroup comparison (haemodynamic, catecholamine, glucose, lactic acid, and blood gas data) between the enflurane and isoflurane groups were analyzed by a two-way analysis of variance from repeated measurements of the same variables. A $P<$ 0.05 was considered statistically significant.

\section{Results}

The MAP in the enflurane group decreased during infusion and remained depressed until $\mathbf{3 0} \mathrm{min}$ after the CGRP infusion was terminated. In the isoflurane group, MAP decreased during infusion. The HR in the enflurane group remained unchanged throughout 
TABLE I Changes in MAP, HR, CI and SVI before, during, and after CGRP infusion in dogs anaesthetized with enflurane (enflurane group, $\mathrm{n}=7$ ) or isoflurane (isoflurane group, $\mathrm{n}=7$ )

\begin{tabular}{|c|c|c|c|c|c|c|c|c|}
\hline \multirow[t]{2}{*}{ Variable } & & \multirow[t]{2}{*}{ Baseline } & \multicolumn{3}{|c|}{ during infusion } & \multicolumn{3}{|c|}{ after infusion } \\
\hline & & & $5 \min$ & $30 \mathrm{~min}$ & $60 \mathrm{~min}$ & $10 \mathrm{~min}$ & $30 \mathrm{~min}$ & $60 \mathrm{~min}$ \\
\hline MAP & Enflurane & $107 \pm 7$ & $88 \pm 7 \dagger$ & $71 \pm 5 \dagger$ & $71 \pm 7 \dagger$ & $90 \pm 8 \dagger$ & $97 \pm 7^{\star}$ & $100 \pm 6$ \\
\hline$(\mathrm{mmHg})$ & Isoflurane & $114 \pm 5$ & $96 \pm 6 \dagger$ & $80 \pm 7 \dagger$ & $86 \pm 7 \dagger$ & $106 \pm 4$ & $111 \pm 4$ & $111 \pm 3$ \\
\hline HR & Enflurane & $135 \pm 6$ & $134 \pm 7$ & $132 \pm 7$ & $134 \pm 7$ & $130 \pm 6$ & $130 \pm 6$ & $130 \pm 6$ \\
\hline (beat.min) & Isoflurane & $162 \pm 9$ & $173 \pm 12$ & $167 \pm 13$ & $171 \pm 9$ & $161 \pm 7$ & $156 \pm 7$ & $154 \pm 7$ \\
\hline CI & Enflurane & $2.3 \pm 0.2$ & $3.0 \pm 0.3 \dagger$ & $3.0 \pm 0.3 \dagger$ & $3.2 \pm 0.3 \dagger$ & $3.2 \pm 0.3 \dagger$ & $3.0 \pm 0.3 \dagger$ & $2.8 \pm 0.3 \dagger$ \\
\hline$\left(1 \cdot \mathrm{min}^{-1} \cdot \mathrm{m}^{-2}\right)$ & Isoflurane & $2.6 \pm 0.1$ & $3.2 \pm 0.2^{*}$ & $3.4 \pm 0.2 \dagger$ & $3.5 \pm 0.2 \dagger$ & $3.4 \pm 0.2$ & $3.0 \pm 0.2$ & $2.7 \pm 0.2$ \\
\hline SVI & Enflurane & $17 \pm 1$ & $23 \pm 2 \dagger$ & $23 \pm 2 \dagger$ & $24 \pm 2 \dagger$ & $25 \pm 2 \dagger$ & $23 \pm 2 \dagger$ & $22 \pm 2 \dagger$ \\
\hline$\left(\mathrm{ml} \cdot\right.$ beat $\left.^{-1} \cdot \mathrm{m}^{-2}\right)$ & Isoflurane & $17 \pm 1$ & $19 \pm 1$ & $21 \pm 1$ & $21 \pm 2$ & $21 \pm 2^{*}$ & $19 \pm 1$ & $18 \pm 1$ \\
\hline
\end{tabular}

Values are mean \pm SEM

$\mathrm{MAP}=$ mean arterial pressure; $\mathrm{HR}=$ heart rate; $\mathrm{CI}=$ cardiac index; $\mathrm{SVI}=$ stroke volume index

$* P<0.05, \dagger P<0.01$ vs baseline

TABLE II Changes in MPAP, PCWP, and SVR before, during, and after CGRP infusion in dogs anaesthetized with enflurane (enflurane group, $\mathrm{n}=7$ ) or isoflurane (isoflurane group, $\mathrm{n}=7$ )

\begin{tabular}{lllllllll}
\hline Variable & & Baseline & \multicolumn{3}{c}{ during infusion } & \multicolumn{2}{c}{ after infusion } \\
& & & $5 \mathrm{~min}$ & $30 \mathrm{~min}$ & $60 \mathrm{~min}$ & $10 \mathrm{~min}$ & $30 \mathrm{~min}$ & $60 \mathrm{~min}$ \\
\hline $\mathrm{MPAP}$ & Enflurane & $13.4 \pm 1.1$ & $13.3 \pm 1.0$ & $13.9 \pm 1.4$ & $14.7 \pm 1.2$ & $15.7 \pm 1.1^{\star}$ & $16.3 \pm 1.0 \dagger$ & $15.3 \pm 1.2$ \\
$(\mathrm{mmHg})$ & Isoflurane & $15.0 \pm 1.1$ & $15.4 \pm 1.4$ & $14.3 \pm 1.6$ & $16.1 \pm 2.2$ & $17.7 \pm 2.2^{\star}$ & $17.3 \pm 1.9$ & $16.9 \pm 1.7$ \\
$\mathrm{PCWP}$ & Enflurane & $\mathbf{8 . 6 \pm 0 . 7}$ & $8.4 \pm 1.3$ & $7.6 \pm 0.6$ & $7.7 \pm 0.7$ & $8.9 \pm 0.9$ & $9.7 \pm 0.8$ & $9.1 \pm 10$ \\
$(\mathrm{mmHg})$ & Isoflurane & $9.7 \pm 1.1$ & $8.6 \pm 1.0$ & $8.0 \pm 1.0^{*}$ & $8.6 \pm 1.2$ & $9.7 \pm 1.0$ & $9.7 \pm 1.0$ & $10.4 \pm 1.0$ \\
SVR & Enflurane & $4904 \pm 506$ & $3021 \pm 303 \dagger$ & $2491 \pm 238 \dagger$ & $2253 \pm 204 \dagger$ & $2860 \pm 296 \dagger$ & $3359 \pm 312 \dagger$ & $3680 \pm 279 \dagger$ \\
$\left(\right.$ dyne $\left.\cdot \mathrm{s} \cdot \mathrm{cm}^{-5}\right)$ & Isoflurane & $4874 \pm 424$ & $3390 \pm 279 \dagger$ & $2559 \pm 241 \dagger$ & $2639 \pm 193 \dagger$ & $3461 \pm 171 \dagger$ & $4032 \pm 159 \dagger$ & $4433 \pm 200$ \\
\hline
\end{tabular}

Values are mean \pm SEM

$\mathrm{MPAP}=$ mean pulmonary artery pressure; $\mathrm{PCWP}=$ pulmonary capillary wedge pressure; $\mathrm{SVR}=$ systemic vascular resistance

${ }^{*} P<0.05, \dagger P<0.01$ ps baseline

the study. In contrast, HR increased sightly during infusion but these changes were not statistically significant. Furthermore, intergroup differences in HR were found $(P<0.05$, a two-way repeated measures ANOVA). The CI in the enflurane group increased throughout the study. The $\mathrm{CI}$ in the isoflurane group increased during infusion. In the enflurane group, there were increases in SVI throughout the study. In contrast, SVI in the isoflurane group did not change during infusion (Table I).

The MPAP in both groups remained unchanged during infusion. The PCWP in the enflurane group remained unchanged but decreased at $30 \mathrm{~min}$ of infusion in the isoflurane group. The SVR in the enflurane group declined throughout the study. In the isoflurane group, SVR declined during infusion but tended to recover to the baseline at $60 \mathrm{~min}$ after the CGRP infusion was terminated (Table II).

Plasma norepinephrine and epinephrine concentrations in the enflurane group remained unchanged throughout the study. Plasma epinephrine and glucose concentrations in the isoflurane group increased during infusion. However, these increases were not observed in the enflurane group. Plasma lactic acid concentrations in both groups increased throughout the study (Table III).

The changes in arterial blood gas variables are summarized in Table IV.

\section{Discussion}

The major findings in the current study are that the haemodynamic responses induced by CGRP infusion during enflurane and isoflurane anaesthesia resulted in a decrease in MAP due to a reduction in SVR in association with an increase in CI. However, the mechanisms causing the increase in $\mathrm{CI}$ differed; the increase in $\mathrm{CI}$ during isoflurane was due to the increases in both $\mathrm{HR}$ and SVI, while the increase in CI during enflurane was due to an increase in SVI alone. The interactions of CGRP with isoflurane versus enflurane demonstrated a lesser degree of positive chronotropic effect with CGRP and enflurane. These effects were associated with a change in plasma catecholamine concentrations and may be due to an anaesthetic-induced sympathetic suppression. The modulation in plasma catecholamine concentrations produced by CGRP infusion during the use of either anaesthetic resulted in alterations in the 
TABLE III Changes in plasma catecholamine, glucose, and lactic acid concentrations before, during, and after CGRP infusion in dogs anaesthetized with enflurane (enflurane group, $n=7$ ) or isoflurane (isoflurane group, $n=7$ )

\begin{tabular}{|c|c|c|c|c|c|}
\hline \multirow{2}{*}{ Variable } & & \multirow{2}{*}{ Baseline } & \multicolumn{2}{|c|}{ during infusion } & \multirow{2}{*}{$\begin{array}{l}\text { after infusion } \\
30 \text { min }\end{array}$} \\
\hline & & & $30 \mathrm{~min}$ & $60 \min$ & \\
\hline $\mathrm{NE}$ & Enflurane & $50.1 \pm 23.0$ & $44.4 \pm 21.7$ & $63.1 \pm 31.1$ & $37.4 \pm 16.8$ \\
\hline$\left(\mathrm{pg} \cdot \mathrm{ml}^{-1}\right)$ & Isoflurane & $48.4 \pm 13.4$ & $83.6 \pm 20.8$ & $134.2 \pm 66.8$ & $103.7 \pm 43.4$ \\
\hline $\mathrm{E}$ & Enflurane & $46.6 \pm 23.2$ & $52.6 \pm 17.9$ & $64.7 \pm 32.4$ & $25.9 \pm 10.8$ \\
\hline$\left(\mathrm{pg} \cdot \mathrm{ml}^{-1}\right)$ & Isoflurane & $42.4 \pm 12.7$ & $122.0 \pm 29.1 \dagger$ & $115.3 \pm 41.8 \dagger$ & $57.9 \pm 21.3$ \\
\hline Glucose & Enflurane & $105.2 \pm 1.7$ & $111.7 \pm 3.2$ & $110.6 \pm 1.9$ & $98.6 \pm 2.2$ \\
\hline$\left(\mathrm{mg} \cdot \mathrm{dl}^{-1}\right)$ & Isoflurane & $110.0 \pm 5.5$ & $127.4 \pm 4.6 \dagger$ & $122.0 \pm 5.4 \dagger$ & $105.3 \pm 4.7$ \\
\hline Lactic acid & Enflurane & $16.5 \pm 1.6$ & $23.1 \pm 1.7 \dagger$ & $24.1 \pm 1.7 \dagger$ & $23.6 \pm 1.7 \dagger$ \\
\hline$\left(\mathrm{mg} \cdot \mathrm{dl}^{-1}\right)$ & Isoflurane & $17.3 \pm 2.3$ & $22.9 \pm 1.9 \dagger$ & $24.0 \pm 1.7 \dagger$ & $22.0 \pm 1.4^{*}$ \\
\hline
\end{tabular}

Values are mean \pm SEM

$\mathrm{NE}=$ plasma norepinephrine concentration; $\mathrm{E}=$ plasma epinephrine concentration; Glucose $=$ plasma glucose concentration;

Lactic acid = plasma lactic acid concentration

$* P<0.05, \dagger P<0.01$ ps baseline

TABLE IV Changes in arterial blood gas analysis before, during, and after CGRP infusion in dogs anaesthetized with enflurane (enflurane group, $\mathrm{n}=7$ ) or isoflurane (isoflurane group, $\mathrm{n}=7$ )

\begin{tabular}{llllll}
\hline Variable & & Baseline & \multicolumn{2}{c}{ during infusion } & \multicolumn{2}{c}{ after infusion } \\
& & & $30 \min$ & 60 min & 30 min \\
\hline $\mathrm{pHa}$ & Enflurane & $7.40 \pm 0.19$ & $7.38 \pm 0.16$ & $7.35 \pm 0.17$ & $7.34 \pm 0.18^{*}$ \\
& Isoflurane & $7.42 \pm 0.05$ & $7.39 \pm 0.14$ & $7.37 \pm 0.13 \dagger$ & $7.36 \pm 0.13 \dagger$ \\
$\mathrm{PaCO}_{2}$ & Enflurane & $39 \pm 1$ & $37 \pm 1$ & $40 \pm 2$ & $41 \pm 2$ \\
$(\mathrm{mmHg})$ & Isoflurane & $36 \pm 2$ & $35 \pm 2$ & $39 \pm 1$ & $44 \pm 5$ \\
$\mathrm{PaO}_{2}$ & Enflurane & $525 \pm 11$ & $525 \pm 10$ & $528 \pm 13$ & $528 \pm 10$ \\
$(\mathrm{mmHg})$ & Isoflurane & $530 \pm 17$ & $525 \pm 13$ & $538 \pm 10$ & $530 \pm 15$ \\
$\mathrm{BE}$ & Enflurane & $-0.9 \pm 0.8$ & $-2.8 \pm 0.8$ & $-3.7 \pm 0.8^{\star}$ & $-3.7 \pm 0.5^{\star}$ \\
$(\mathrm{mEq} \cdot 1)$ & Isoflurane & $-0.5 \pm 0.7$ & $-2.9 \pm 0.9$ & $-3.7 \pm 0.7^{*}$ & $-3.3 \pm 0.5^{*}$ \\
\hline
\end{tabular}

Values are mean \pm SEM

$\mathrm{pHa}=$ arterial $\mathrm{pH}, \mathrm{PaCO}_{2}=$ partial pressure of carbon dioxide in arterial blood; $\mathrm{PaO}_{2}=$ partial pressure of oxygen in arterial blood; $\mathrm{BE}=$ base excess

* $P<0.05, \dagger P<0.01$ vs baseline

haemodynamic and metabolic effects.

The haemodynamic responses observed, except for $\mathrm{HR}$, during CGRP administration in the current study were similar to earlier studies, reporting that CGRP in conscious humans ${ }^{5}$ and animals ${ }^{7,8}$ elicited hypotension, vasodilatation, and reflex tachycardia. The baroreflexmediated increase in sympathetic tone and/or the decrease in parasympathetic tone seem to be involved in the haemodynamic responses associated with CGRP administration. Because tachycardia induced by CGRP was markedly attenuated in sinoaortic-denervated rats ${ }^{7}$ and in cardiac-denervated $\operatorname{dogs}^{8}$, the increase in HR is thought to be mediated primarily by the autonomic nervous system in intact animals. In addition, reflex sympathetic activation as a mechanism for tachycardia induced by CGRP is supported by the suppression of tachycardia caused by the beta adrenoceptor blocker, propranolol. ${ }^{9}$

Volatile anaesthetics depress baroreflex activity the extent of depression varies among anaesthetics; isoflurane is less depressant than enflurane. ${ }^{11,12}$ The HR tended to increase in proportion to the magnitude of hypotension in the isoflurane group because depression of sympathetic nerve activity at isoflurane $1.5 \%$ seems to be countered by reflex increases in sympathetic tone due to the hypotension accompanying the anaesthesia. ${ }^{16}$ In contrast, the increase in HR during CGRP infusion in the enflurane group was almost completely inhibited despite a greater reduction of MAP. There were also differences between the groups in changes of HR throughout observation. The suppressive patterns of $H R$ in the enflurane group are similar to those of halothane-anaesthetized dogs at concentrations of 1.0 MAC using an identical experimental protocol. ${ }^{13}$ These findings indicate that differences among volatile anaesthetics in the effects on HR were due to the differences in the potency of suppression caused by halothane, enflurane, and isoflurane on the baroreflexes and sympathetic nerve activity.

Consistent with several reports, ${ }^{4-9}$ the isoflurane group produced increases in plasma epinephrine con- 
centrations during CGRP administration. Plasma norepinephrine concentrations tended to increase in response to increased plasma epinephrine concentrations because epinephrine activation is known to act presynaptically to enhance norepinephrine release from sympathetic nerve endings. ${ }^{17}$ However, the enflurane group completely suppressed the increases in plasma norepinephrine and epinephrine concentrations. The results of the current study showed that isoflurane can partly suppress catecholamine responses to vasodilatation induced by CGRP, but enflurane induces complete suppression of the increase in plasma catecholamine concentrations. These differing results may have resulted from the effects of volatile anaesthetics that may produce differential suppression of autonomic reflexes. ${ }^{10-12}$ The attenuation of the sympathetic tone due to isoflurane or enflurane may be the mechanism of the suppression of the tachycardic effect and activation of the vasodilatory activity induced by CGRP. Another explanation may be that the magnitude of reflex sympathetic activation with volatile anaesthetics can oppose the effects of the vasodilatory activity of CGRP. These findings suggest that adequate sympathetic activation may be necessary for the maintenance of haemodynamic stability with CGRP. The preservation of the baroreflex responses is believed to be important for haemodynamic stability during anaesthesia and surgery. Therefore, the use of CGRP as a vasodilator agent during enflurane anaesthesia may not be suitable when rapid recovery from hypotension is desired.

Plasma glucose concentrations increased in the isoflurane group but not in the enflurane group. Calcitonin gene-related peptide has been shown to increase plasma glucose concentration in vivo. ${ }^{18-20}$ Yamaguchi et al..$^{20}$ have reported no involvement of sympathetic outflow on the effects of CGRP on glucose metabolism, because the increase in plasma catecholamine concentrations after CGRP administration does not elicit any change in insulin-mediated glucose metabolism. However, epinephrine acts on hepatocytes to facilitate the conversion of hepatic glycogen to glucose-6-phosphate, which then may be converted to glucose by the liver, thus inducing hyperglycemia, increasing lactic acid concentration, and decreasing muscle and hepatic glycogen content. ${ }^{21}$ Furthermore, the physiological thresholds of plasma epinephrine concentrations for the increase in plasma glucose and blood lactate, and the decrease in plasma insulin have been shown to be $150-200 \mathrm{pg} \cdot \mathrm{ml}^{-1}$ and > $400 \mathrm{pg} \cdot \mathrm{ml}^{-1}$, respectively. ${ }^{22}$ Calcitonin gene-related peptide also stimulates adenylate cyclase activity in the liver and skeletal muscles, suggesting that activation of adenylate cyclase may contribute to the decreased insulin sensitivity and suggesting a possible role for neuropeptides in the modulation of glucose metabolism. ${ }^{23}$ Although the mechanism for the differing changes in plasma glucose concentrations between the enflurane and isoflurane groups remains unclear, it may be attributable to differences in the phosphorylase activity of anaesthetics. Reynolds ${ }^{24}$ has demonstrated that anaesthetics differ in their abilities to alter epinephrine-induced phosphorylase activation, suggesting that this characteristic of the anaesthetics may alter glucose metabolism.

The plasma lactic acid concentrations are reflected in the production of lactic acid produced by many tissues and in the removal of lactic acid metabolised primarily by the liver. Increased plasma lactic acid concentrations reflect not only from overproduction due to enhanced anaerobic metabolism, but from decreased hepatic removal. Increased plasma lactic acid concentrations are unlikely to have resulted from overproduction due to enhanced anaerobic metabolism caused by haemodynamic dysfunction (hypoperfusion) because the arterial blood gas values were similar between the groups during CGRP infusion, and the arterial blood gas data of both groups did not show $\mathrm{pHa}$ values $<7.34$ and base excess values < -3.7 (Table IV). Furthermore, there is no possibility that other enhanced anaerobic mechanisms caused by respiratory (hypoxia), haematological (anaemia), or cellular (mitchondrial abnormality) dysfunction may lead to lactic acid overproduction. On the other hand, the increases in plasma lactic acid concentrations are of the same magnitude with or without the changes in the plasma glucose concentrations. The increased lactic acid concentrations in the isoflurane group seem to be involved in the plasma glucose changes associated with sympathetic activation, although increased lactic acid concentrations in the enflurane group seem to be caused by the reduction in hepatic removal, because enflurane decreases hepatic blood flow to a greater extent than does isoflurane at 1.0 MAC concentration. ${ }^{25,26}$

These haemodynamic, endocrine, and metabolic profiles of CGRP during enflurane or isoflurane anaesthesia suggest that CGRP may play a valuable therapeutic role in the perioperative period in inducing hypotension and controlling hypertension during surgery under volatile anaesthetics.

In conclusion, our results show that haemodynamic responses induced by CGRP are similar during both enflurane and isoflurane anaesthesia, but that the suppression of tachycardia is greater with enflurane than with isoflurane. The difference between enflurane and isoflurane is most likely due to the way the endocrine system responds to these anaesthetic agents. The 
interactions of CGRP with enflurane or isoflurane may directly suppress the activation of the sympathetic nervous system and may indirectly modulate systemic haemodynamic and metabolic effects. These findings suggest that CGRP administration during isoflurane anaesthesia preserves acceptable sympathetic activity such as moderate increases in plasma catecholamines, and may provide a greater margin of safety with respect to haemodynamic stability than the use of CGRP with enflurane anaesthesia.

\section{Acknowledgments}

The authors gratefully thank Yoshie Hirakawa for her excellent secretarial assistance. Des-1-Ala, des- $\alpha$-amino chicken CGRP was kindly provided by Asahi Chemical Industry, Tokyo, Japan.

\section{References}

1 Amara SG, Jonas V, Rosenfeld MG, Ong ES, Evans RM. Alternative RNA processing in calcitonin gene expression generates mRNAs encoding different polypeptide products. Nature $1982 ; 298: 240-4$.

2 Fisher JA, Born W. Calcitonin gene products: evolution, expression and biological targets. Bone and Mineral 1987; 2: 347-59.

3 Struthers AD, Brown MJ, MacDonald DWR, et al. Human calcitonin gene related peptide: a potent endogenous vasodilator in man. Clin Sci 1986; 70: 389-93.

4 Gennari C, Fisher JA. Cardiovascular action of calcitonin gene-related peptide in humans. Calcif Tissue Int $1985 ; 37: 581-4$.

5 Franco-Cereceda A, Gennari $C$, Nami $R$, et al. Cardiovascular effects of calcitonin gene-related peptides I and II in man. Circ Res 1987; 60: 393-7.

6 Fisher LA, Kikkawa DO, Rivier JE, et al. Stimulation of noradrenergic sympathetic outflow by calcitonin generelated peptide. Nature $1983 ; 305: 534-6$.

7 Sirén $A-L$, Feuerstein $G$. Cardiovascular effects of rat calcitonin gene-related peptide in the conscious rat. J Pharmacol Exp Ther 1988; 247: 69-78.

8 Wang BC, Bie P, Leadley RJ Jr, Goetz KL. Cardiovascular effects of calcitonin gene-related peptide in conscious dogs. Am J Physiol 1989; 257: R726-31.

9 Lappe RW, Slivjak MJ, Todt JA, Wendt RL. Hemodynamic effects of calcitonin gene-related peptide in conscious rats. Regul Pept 1987; 19: 307-12.

10 Morton M, Duke PC, Ong B. Baroreflex control of heart rate in man awake and during enflurane and enfluranenitrous oxide anesthesia. Anesthesiology 1980; 52: 221-3.

11 Kotrly KJ, Ebert TJ, Vucins E, Igler FO, Barney JA, Kampine JP. Baroreceptor reflex control of heart rate during isoflurane anesthesia in humans. Anesthesiology 1984; 60: 173-9.
12 Takesbima $R$, Dobi S. Comparison of arterial baroreflex function in humans anesthetized with enflurane or isoflurane. Anesth Analg 1989; 69: 284-90.

13 Takeda $S$, Inada $Y$, Matsui $K$, Tomaru T. Halothane anesthesia suppresses reflex tachycardia caused by calcitonin gene-related peptide in dogs. J Anesth 1996; 10: 58-62.

14 Drummond JC. MAC for halothane, enflurane, and isoflurane in the New Zealand white rabbit: and a test for the validity of MAC determinations. Anesthesiology 1985; 62: 336-8.

15 Guyton AC, Jones CE, Coleman TG. Normal cardiac output and its variations. In: Circulatory Physiology: Cardiac Output and its Regulation, 2nd ed. Philadelphia: W.B. Saunders Company, 1973: 3-20.

16 Seagard JL, Hopp FA, Bosnjak ZJ, Osborn JL, Kampine JP. Sympathetic efferent nerve activity in conscious and isoflurane-anesthetized dogs. Anesthesiology 1984; 61: 266-70.

17 Majewski $H$, Rand MJ, Tung L-H. Activation of prejunctional $B$-adrenoceptors in rat atria by adrenaline applied exogenously or released as a co-transmitter. $\mathrm{Br}$ J Pharmacol 1981; 73: 669-79.

18 Pettersson $M, A b r e ́ n ~ B$. Insulin and glucagon secretion in rats: effects of calcitonin gene-related peptide. Regul Pept 1988; 23: 37-50.

19 Abrén B, Mårtensson $H$, Nobin $A$. Effects of calcitonin gene-related peptide(CGRP) on islet hormon secretion in the pig. Diabetologia 1987; 30: 354-9.

20 Tamaguchi A, Chiba $T$, Morishita $T$, et al. Calcitonin gene-related peptide and induction of hyperglycemia in conscious rats in vivo. Diabetes $1990 ; 39: 168-74$.

21 Coben PJ. More on lactate. Anesthesiology 1975; 43: 614-6.

22 Clutter WE, Bier DM, Shab SD, Cryer PE. Epinephrine plasma metabolic clearance rates and physiologic thresholds for metabolic and hemodynamic actions in man. J Clin Invest 1980; 66: 94-101.

23 Yamaguchi $A$, Chiba $T$, Yamatani $T$, et al. Calcitonin gene-related peptide stimulates adenylate cyclase activation via a guanine nucleotide-dependent process in rat liver plasma membranes. Endocrinology 1988; 123: 2591-6.

24 Reynolds RC. Effects of halothane, methoxyflurane, and cyclopropane on activation of phosphorylase in skeletal muscle by epinephrine. Anesthesiology 1974; 41: 444-51.

25 Bernard J-M, Doursout $M-F$, Wouters $P$, et al. Effects of enflurane and isoflurane on hepatic and renal circulations in chronically instrumented dogs. Anesthesiology 1991; 74: 298-302.

26 Frink EJ Jr, Morgan SE, Coetzee A, Conzen PF, Brown BR Jr. The effects of sevoflurane, halothane, enflurane, and isoflurane on hepatic blood flow and oxygenation in chronically instrumented greyhound dogs. Anesthesiology 1992; 76: 85-90. 